\title{
books and arts
}

with strong cross-immunity, and influenza. For retroviruses such as HIV that lead to persistent infection, the prospects for a vaccine are dim; their diversity exists both in the individual and in the population as a whole. Until we have an effective AIDS vaccine, people will need the education and resources to modify their behaviour. Unless we change our way of life, Goudsmit warns, the emergence of viral threats to human health looms large.

Steven Wolinsky is in the Feinberg School of Medicine, Northwestern University, Chicago, Illinois 60611, USA.

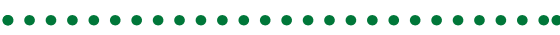 Peering out of the box}

\section{Pioneering Research: A Risk Worth Taking \\ by Donald W. Braben \\ Wiley: 2004. 198 pp. £23.50, \$39.95, €33.30 \\ Nina Fedoroff}

Donald Braben's book begins with the idea that the unique quality of Homo sapiens is not wisdom, but rather the capacity for dissent. By this he means not the transient dissatisfactions that spark violence at sports events, for instance, but the dissent that emerges from "an individual's overwhelming conviction that some aspect of life has become unbearable". Braben believes it is this characteristic of humans that gives rise to scientific discovery of the kind that changes our view of the world, be it Galileo's restructuring of the Universe or Barbara McClintock's transposons, which overthrew the notion that genomes are static. And because it is increasingly recognized that science and technology power contemporary economic growth, it follows that the freedom to challenge the prevailing thinking is essential not just to deepen our understanding of the world, but to sustain economic growth as well.

Suppressing dissent leads to both scientific sterility and economic stagnation, be it in Europe in the Dark Ages or in the Soviet Union not so very long ago. But, more ominously, Braben argues that what suppresses scientific invention today isn't religious dogma or a political regime (although some contemporary observers of US politics might argue otherwise). Rather, it is the well intentioned bureaucracy of the system for awarding grants and the way it operates in a resource-limited environment that is at once egalitarian and increasingly mindful of cost-effectiveness.

Braben argues that until the last few decades, scientists with unconventional ideas could afford to ignore the opinions of their colleagues. But not any more. This is

\section{Video installation}

\section{Twin peaks}

London Fieldworks artists Bruce Gilchrist and Jo Joelson have explored the work of two scientists who studied the weather from mountain-top observatories in the nineteenth century, and who went on to develop instruments that presaged the development of particle physics and space plasma physics.

C. T. R. Wilson observed visual phenomena such as the 'Brocken spectre' in the skies above Ben Nevis in Scotland when working as a relief meteorologist. He went on to develop the cloud chamber, which enables the visualization of the tracks of subatomic particles, earning a Nobel prize for his efforts.

Kristian Birkeland's observations of the aurora borealis from the summit of Haldde in Norway inspired him to build the terrella, which models

the aurora's relationship to solar activity.

Little Earth, a video installation that explores this move from lone observers of nature to an era of technological and abstract science, can be seen at the Wapping Project in London until 12 February, and then at the Fort William Mountain Film Festival in Scotland until 3 March.

www.Iondonfieldworks.com because "selected groups of their fellow experts now have responsibility for setting priorities and allocating resources. Consensus opinion cannot be ignored." What he's talking about, of course, is the peer-review system: panels of experts who gather all over the planet to decide which research proposals are worth funding and which are not. But, Braben says: "An expert opinion is one thing; the consensus of experts is another." He goes on: "Unfortunately, science and democracy are poor bedfellows... No matter how many agree on the validity of a point of view, a single person with a more viable, accurate, or comprehensive alternative may overthrow it."Well said, and all too true.

One might question Braben's anthropology and history, but he certainly has the credentials to comment on contemporary scientific bureaucratization. After almost two decades as an academic nuclear and elementary particle physicist, he joined the ranks of scientific administrators, first in the UK Cabinet Office and later in the Science Research Council. There he had responsibility for the Marine Technology Directorate, which funded marine technology research, and the Teaching Company, whose objective was to bring academic engineers together with industry. He also worked as chief scientist at the Bank of England printing works.

Braben was then recruited by the energy company BP in 1980 to head its 'blue skies' research initiative, which came to be called the Venture Research Unit. The unit's mission was simply "to support the research that might lead to new types of industrial activity". Constrained by neither a specific mission nor an 80-page manual for the preparation of grant proposals, but only by a limited budget, he could make it up as he went along. Well, almost: he still had to convince the members of BP's Venture Research Advisory Council, all of whom were fellows of the Royal Society, and all of whom objected to his abolition of peer review as the mechanism for funding research, a system they didn't think needed fixing.

But instead of focusing on grant proposals, Braben insisted on choosing people, treating their selection "as if it were a scientific problem rather than an administrative one" and struggling "constantly to reduce the number of rules" imposed on applicants. In Braben's view, "the highest accolade one can give a new research proposal is that it could radically change the way we think about something important." That's why he sought researchers whose thinking was decidedly out of the box, working diligently to make sure that it wasn't merely out to lunch - not an easy task on which to score well.

I unreservedly recommend this book to anyone who has puzzled over the growing malaise of contemporary scientific research: we build virtual mountains of data, but where are the paradigm-busters? Braben says they're still there, but that the system is almost guaranteed to filter them out.

I think he has got the diagnosis right. Does he also have the cure? I leave it to others to judge Braben's personal success rate, but the prescription is certainly inviting: pick people and their ideas, not projects; trust them, they'll know when it's time to stop or change direction; provide freedom and sufficient money; expect radical ideas, and expect them to meet with resistance, at least initially. That seems a bit revolutionary to those of us who have grown accustomed to the proposal grind: specific objectives, preliminary data, experimental plan, deliverables and timeline. Small wonder then that there's no time to wander off the beaten path.

$\mathrm{Oh}$, and did I say that this book is a surprisingly good read? Braben is literate, pithy and personable.

Nina Fedoroff is at the Huck Institutes of the Life Sciences, Pennsylvania State University, University Park, Pennsylvania 16802, USA. 